\title{
EKSEPSI PLURIUM LITIS CONSORTIUM (Studi Terhadap Putusan Pengadilan Tinggi Semarang No. 401/Pdt/2002/PT. Smg jo. Putusan Pengadilan Negeri Purwokerto No.41/Pdt.G/2000/PN.Pwt)*
}

\author{
Oleh : \\ Siti Muflichah, Trusto Subekti dan Haedah Faradz \\ Fakultas Hukum Universitas Jenderal Soedirman Purwokerto
}

\begin{abstract}
In the civil jurisdiction, truth searched is the formal truth. This matter of course different from the criminal justice, where truth searched is material truth. Searching the formal truth, meaning that judge may not be abysmal of boundary that raised by the parties. This matter contain the congeniality, that verification process is not see at wight or content, but to wide of case scope or dispute that raised by the parties. In this case judge have the passive character. in civil jurisdiction, truth searched is a truth that relying on formal verification. The Judge decision shall contain the rule of law element, justice and benefit. For the reason judge have to careful, goodness in making draft of decision and also decision intake later. In Case No. 401/ Pdt / 2002 / PT. Smg, The Judge of High Court of middle of Java made the decision by strengthening decision of District Court of Purwokerto in case No. 41/Pdt.G/2000/PN Pwt. This Judge Decision represent an example of careless of the judge in make decision. exception of the lack of party had refused. Therefore, judge have to consider this matter in its decision. Therefore, judge have to consider this matter in its decision. This matter of course relative harm the plaintiff, because if suing is not accepted, plaintiff can improve/ repair its suing or make a lawsuit to the court newly again. But refusedly of suing make the plaintiff cannot improve/ repair its suing or make the new suing again. finally, the decision which is not careful will not fulfill the rule of law elements, justice and benefit.
\end{abstract}

Kata kunci: kebenaran formil, penggugat, tergugat, turut tergugat, syarat formil gugatan

\section{A. Pendahuluan}

Proses peradilan perdata diawali dengan adanya suatu gugatan maupun permohonan. Pihak yang mempunyai kepentingan wajib mengajukan gugatan. Dalam suatu gugatan disyaratkan adanya kepentingan hukum. Walaupun undang-undang tidak mensyaratkan adanya dasar suatu gugatan, karena menjadi tugas hakim untuk mengkualifisir aturan hukum yang tepat, tetapi suatu gugatan harus didasarkan atas suatu alas hukum yang jelas, agar lebih menguatkan dalil-dalil yang diajukan. Alas hukum yang dijadikan dasar suatu gugatan dalam praktek adalah wanprestasi, Perbuatan Melawan Hukum (PMH), pembagian waris dan perceraian.

Dalam suatu peradilan perdata, kebenaran yang dicari adalah kebenaran formil. Hal ini tentu saja berbeda dengan peradilan pidana, dimana kebenaran yang dicari adalah kebenaran materiil. Mencari kebenaran formil menurut Sudikno Mertokusumo berarti bahwa hakim tidak boleh melampaui batas-batas yang diajukan oleh para pihak yang berperkara. ${ }^{1} \mathrm{Hal}$ ini mengandung pengertian, bahwa proses pembuktian nantinya tidak melihat pada bobot atau isi, melainkan kepada luas ruang lingkup perkara atau sengketa yang diajukan oleh para pihak. Dalam hukum acara perdata pada prinsipnya pemeriksaan perkara dilakukan dalam suatu ruang sidang yang khusus ditentukan untuk itu. Sidang itu pun harus dinyatakan ter-

Artikel ini merupakan artikel hasil penelitian dengan biaya dari Anggaran DIPA FH Unsoed 2007

Sudikno Mertokusumo, 2002, Hukum Acara Perdata Indonesia. Yogyakarta: Liberty, hlm. 130 
buka untuk umum, ${ }^{2}$ kecuali undang-undang melarangnya.

Keseluruhan pihak yang berkaitan dengan obyek sengketa baik secara langsung maupun tidak langsung harus dimasukkan dalam gugatan. Tidak digugatnya pihak-pihak tersebut mengakibatkan gugatan tidak dapat diterima. Dalam hukum acara perdata tidak dikenal istilah turut penggugat, melainkan turut tergugat. Disebutkan sebagai turut tergugat dimaksudkan agar orang-orang, bukan para pihak yang bersengketa (penggugat dan tergugat) demi lengkapnya pihak-pihak, maka orang-orang bukan pihak yang bersengketa tersebut harus diikutsertakan dalam gugatan penggugat sekedar untuk tunduk dan taat terhadap putusan hakim. Hal ini telah menjadi suatu yurisprudensi sebagaimana diputus dalam Putusan Mahkamah Agung tanggal 28 Januari 1976 No. $201 \mathrm{~K} / \mathrm{Sip} / 1974 .^{3}$

Pada saat suatu peristiwa yang disengketakan telah diajukan suatu pembuktian, maka atas pembuktian tersebut harus dinilai oleh hakim. Dalam hal ini pembentuk Undangundang dapat mengikat hakim pada alat-alat bukti tertentu, sehingga hakim tidak bebas untuk menilainya. Selain itu pembentuk Undang-undang juga dapat menyerahkan kepada hakim untuk menilai suatu pembuktian. Proses pembuktian dan penilainnya hanya dilakukan di judex factie saja, yaitu di tingkat pengadilan tingkat I dan pengadilan tingkat II. HIR menentukan secara limitatif alat-alat bukti yang dapat diajukan dalam suatu persidangan perkara perdata, sebagai mana diatur dalam Pasal 164 HIR antara lain yaitu bukti surat, saksi, persangkaan, pengakuan dan sumpah. Selain itu masih ada alat bukti lain di luar Pasal 164 HIR yaitu pemeriksaan setempat (Pasal 153 HIR) dan keterangan ahli (Pasal 154 HIR).

Dalam tulisan ini, penulis menganalisis Putusan Pengadilan Tinggi Semarang No. 401/ Pdt/2002/PT. Smg. Dalam Putusan Perkara No. 401/Pdt/2002/PT. Smg, Majelis Hakim Peng-

Wirjono Prodjodikoro, 1978, Hukum Acara Perdata di Indonesia, Bandung: Sumur Bandung, hlm. 30

Chidir Ali, 1985, Yurisprudensi Hukum Acara Perdata Indonesia, Yogyakarta: CV Nur Cahya, hlm. 218 adilan Tinggi Semarang menjatuhkan putusan dengan menguatkan putusan Pengadilan Negeri Purwokerto No. No. 41/Pdt.G/2000/PN.Pwt. Dalam perkara ini, majelis hakim mengadili sengketa antara Tirtadja sebagai Penggugat melawan :

1. Bambang Suwoyo sebagai Tergugat I,

2. Departemen Keuangan RI cq Badan Urusan Piutang dan Lelang Negara Wilayah V Semarang cq Kantor Pelayanan Pengurusan Piutang Negara Purwokerto sebagai Tergugat II,

3. Bank Pembangunan Daerah Jawa Tengah cabang Purwokerto, sebagai Tergugat III

Pokok perkara yang persengketakan adalah sebagai berikut:

1. Tergugat I meminjam Sertifikat Hak Milik No. 1328 atas nama Penggugat seluas 13.145 m2 yang terletak di Desa Tambaksogra Kecamatan Sumbang Kabupaten Banyumas dengan batas-batas sebagi berikut:

Sebelah Utara : Madisuwito/ saluran air

Sebelah Selatan : jalan raya

Sebelah Barat : tanah desa

Sebelah Timur : saluran air

2. Tergugat I tanpa sepengetahuan Penggugat mengalihkan transaksi pinjam meminjam menjadi jual beli dengan akta jual beli No. 574.SBG/XII/1994. Kemudian tanah tersebut, selanjutnya disebut sebagai obyek sengketa, dijadikan jaminan di Bank BPD Jateng cabang Purwokerto (Tergugat III) dan akan dieksekusi dengan cara dilelang oleh Tergugat II, karena pinjaman Tergugat I mengalami kredit macet.

Dalam perkara ini, Pembanding/Penggugat, tdak dapat membuktikan dalil-dalilnya sehingga gugatan dan permohonan bandingnya ditolak.

Berdasarkan hal tersebut, penulis tertarik membahas mengenai pembuktian dan pertimbangan hukum hakim Pengadilan Negeri Purwokerto dan Pengadilan Tinggi Semarang dalam menjatuhkan putusannya, serta terpenuhinya unsur-unsur kepastian hukum, keadilan dan manfaat dalam putusan hakim ini.

\section{B. Pembahasan}

Tugas hakim adalah mengkonstatir, mengkualifisir dan mengkonstituir. Dalam mengkons- 
tatir suatu sengketa, maka harus dilakukan upaya pembuktian. Pasal 163 HIR (Pasal 283 Rbg) jo. Pasal 1865 BW merumuskan bahwa:

"Barang siapa mengatakan suatu hak atau mengatakan suatu perbuatan untuk meneguhkan haknya atau untuk membantah hak orang lain, haruslah membuktikan hak itu atau adanya perbuatan itu."

Berdasarkan perumusan tersebut, maka pihak yang dibebani suatu pembuktian adalah para pihak yang mendalilkan suatu hak atau perbuatan yang mengukuhkan haknya tersebut. Selain itu pihak yang menyangkal hak orang lain juga harus dibebani pembuktian.

Dalam suatu proses pembuktian yang harus dibuktikan adalah peristiwa dan bukan hukumnya. Hukum tidak perlu dibuktikan oleh para pihak, karena hakim dianggap tahu akan hukumnya. Hal ini dikenal dngan asas ius curia novit. Hal utama yang harus dilakukan hakim dalam hukum acara perdata adalah menemukan dan menentukan peristiwanya atau hubungan hukumnya dan kemudian memperlakukan atau menerapkan hukumnya terhadap peristiwa yang telah diterapkan tersebut. Tidak semua peristiwa itu harusdibuktikan, tetapi hanya peristiwa yang relevan dengan pokok perkara saja yang harus dibuktikan.

Dalam suatu peradilan perdata, kebenaran yang dicari adalah kebenaran formil. Hal ini tentu saja berbeda dengan peradilan pidana, dimana kebenaran yang dicari adalah kebenaran materiil. Mencari kebenaran formil menurut Sudikno Mertokusumo berarti bahwa hakim tidak boleh melampaui batas-batas yang diajukan oleh para pihak yang berperkara. Hal ini mengandung pengertian, bahwa proses pembuktian nantinya tidak melihat pada bobot atau isi, melainkan kepada luas ruang lingkup perkara atau sengketa yang diajukan oleh para pihak. Dalam hal ini hakim bersifat pasif. Kebenaran yang dicari dalan peradilan perdata adalah suatu kebenaran yang mendasarkan pada suatu pembuktian yang lebih bersifat formal.

Pembentuk undang-undang dapat mengikat hakim terkait alat-alat bukti tertentu yang diajukan, sehingga hakim tidak bebas untuk menilainya. Selain itu pembentuk Undangundang juga dapat menyerahkan kepada hakim untuk menilai suatu pembuktian. Proses pembuktian dan penilainnya hanya dilakukan di judex factie saja, yaitu di tingkat pengadilan tingkat I dan pengadilan tingkat II. HIR menentukan secara limitatf alat-alat bukti yang dapat diajukan dalam suatu persidangan perkara perdata, sebagai mana diatur dalam Pasal 164 HIR antara lain yaitu bukti surat, saksi, persangkaan, pengakuan dan sumpah. Selain itu masih ada alat bukti lain di luar Pasal 164 HIR yaitu pemeriksaan setempat (Pasal 153 HIR) dan keterangan ahli (Pasal 154 HIR).

Suatu pembuktian mempunyai nilai kekuatan pembuktian yang harus dipertimbangkan oleh hakim dalam menjatuhkan putusannya. Kekuatan pembuktian tersebut antara lain yaitu:

1. Bukti mengikat dan menentukan

Bukti mengikat dan menentukan mengandung arti bahwa sekalipun hanya ada satu alat bukti, telah cukup bagi hakim untuk memutus perkara berdasarkan alat bukti tersebut tanpa membutuhkan alat bukti lain. Hakim terikat dengan bukti tersebut, sehingga tidak dapat memutus lain dari yang telah terbukti dengan satu alat bukti tersebut. Alat bukti ini tidak dapat dilumpuhkan dengan bukti lawan. Contohnya sumpah decisoir (Pasal 156 HIR, Pasal 183 Rbg), sumpah dilatoir (Pasal 177 HIR, Pasal 183 Rbg), Pengakuan (Pasal 174 HIR, Pasal $311 \mathrm{Rbg})$

2. Bukti sempurna

Kekuatan pembuktian yang sempurna berarti meskipun hanya ada satu alat bukti, telah cukup bagi hakim untuk memutus perkara berdasar alat bukti yang diajukan dan tidak memerlukan adanya alat bukti lain. Hakim terikat dengan bukti tersebut, kecuali jika dapat dibuktikan sebaliknya. Alat bukti yang mempunyai kekuatan pembuktian yang sempurna dapat dilumpuhkan dengan bukti lawan, misalnya akta otentik (Pasal 165 HIR, Pasal 285 Rbg), Pasal 1394 BW (apabila tergugat dapat menunjukkan tiga kwitansi 
pembayaran tiga bulan berturut-turut, maka angsuran yang sebelumnya harus dianggap telah lunas), Pasal 1965 BW (itikad baik selamanya harus dianggap ada, sedangkan siapa yang menunjuk pada itikad buruk diwajibkan membuktikan)

3. Bukti bebas

Hakim bebas untuk menilai sesuai dengan pertimbangan yang logis. Hakim tidak terikat dengan alat bukti tersebut. Terserah kepada keyakinan hakim untuk menilai. Dalam hal ini, hakim dapat mengesampingkan alat bukti ini dengan pertimbangan yang logis. Bukti ini dapat dilumpuhkan dengan bukti lawan, misalnya: saksi yang disumpah (Pasal 172 HIR, Pasal 307 Rbg), meskipun ada 10 orang saksi, jika hakim ragu-ragu, maka hakim tidak terikat atau wajib mempercayai saksi-saksi tersebut. Saksi ahli (Pasal 154 HIR, Pasal 181 Rbg), Pengakuan di luar sidang (Pasal 175 HIR, Pasal 312 Rbg)

4. Bukti Permulaan

Bukti permulaan mengandung maksud, bahwa sekalipun alat bukti tersebut sah dan dapat dipercaya kebenarannya, tetapi belum mencukupi syarat formil sebagai alat bukti yang cukup. Bukti tersebut masih perlu (harus) ditambah dengan alat bukti lain agar menjadi sempurna. Dalam hal ini, hakim bebas dan tidak terikat dengan alat bukti tersebut. Bukti ini dapat dilumpuhkan dengan bukti lawan, misalnya alat bukti saksi yang terdiri dari satu orang (Pasal 136 HIR, 306 Rbg), sehingga harus ditambah dengan alat bukti lain seperti sumpah supletoir, akta di bawah tangan yang dipungkiri tanda tangan dan isinya oleh yang bersangkutan (Pasal 165 HIR, Pasal 289 Rbg)

5. Bukti bukan bukti

Hal ini mengandung maksud, bahwa sekalipun suatu alat bukti tampak memberi keterangan yang mendukung kebenaran suatu peristiwa, tetapi alat bukti tersebut tidak memenuhi syarat formil sebagai alat bukti yang sah. Alat bukti tersebut tidak mempunyai kekuatan pembuktian dan tampak seperti bukti tetapi bukan bukti, seperti halnya: saksi yang tidak disumpah (Pasal 145
(4) HIR, $172 \mathrm{Rbg}$ ), saksi yang belum cukup umur 15 tahun, foto-foto, rekaman kaset/ video, kesaksian tak langsung (Pasal 717 HIR, Pasal 308 Rbg)

Dalam Perkara No. 401/Pdt/2002/PT. Smg, Majelis Hakim Pengadilan Tinggi Jawa Tengah menjatuhkan putusan dengan menguatkan Putusan Pengadilan Negeri Purwokerto, dimana Pembanding, dalam hal ini Penggugat, tidak dapat membuktikan dalil-dalilnya. Oleh karena itu, pertimbangan-pertimbangan Pengadilan Negeri Purwokerto termasuk juga pertimbangan Majelis Hakim Pengadilan Tinggi Semarang.

1. Dalam Eksepsi

Putusan No. 401/Pdt/2002/Smg, Mejelis Hakim Pengadilan Tinggi Semarang menguatkan Putusan Pengadilan Negeri Purwokerto tanggal 17 April 2001 No. 41/Pdt.G/2000/PN Pwt. Persengketaan dalam putusan yang dijatuhkan, bermula dari peristiwa, dimana Tergugat I meminjam sertifikat tanah Hak Milik No. 1328 dari penggugat, kemudian tanpa sepengetahuan Penggugat, Tergugat I mengalihkannya menjadi transaksi jual beli antara Penggugat dengan Tergugat I seharga Rp. 15.000.000,(lima belas juta rupiah) dan kemudian Tergugat I membalik nama sertifikat tersebut atas namanya. Tergugat I mengagunkan obyek sengketa tersebut kepada Tergugat III. Di kemudian hari ternyata Tergugat I tidak dapat mengembalikan pinjamannya kepada Tergugat III, sehingga kemudian Tergugat III menyerahkan penyelesaian pengembalian uang tersebut kepada Tergugat II. Tergugat I dinyatakan kreditur macet, sehingga Tergugat II akan melelang obyek sengketa tersebut.

Eksepsi secara umum berarti pengecualian. Dalam konteks Hukum Acara bermakna tangkisan, bantahan maupun pembelaan yang diajukan Tergugat terhadap materi pokok gugatan Penggugat. ${ }^{4}$ Dalam putusan tersebut, eksepsi yang diajukan ter-

Yahya Harahap, 2005, Hukum Acara Perdata Tentang Gugatan, Persidangan, Penyitaan, Pembuktian dan Putusan Pengadilan, Jakarta: Sinar Grafika, hlm. 418 
gugat/terbanding, berkaitan dengan kurangnya para pihak yang digugat, ditolak. Sementara di sisi lain, proses jual beli antara Penggugat dan Tergugat I melibatkan Muhammad Turman, S.H. sebagai Notaris/ PPAT. Selain itu proses pembebanan hak oleh Tergugat I kepada Tergugat III tentu saja melibatkan pejabat yang berwenang pula dan oleh karenanya, pihak-pihak tersebut harus turut digugat oleh Penggugat.

Tidak dimasukkannya pihak-pihak tersebut dalam surat gugatan akan mengakibatkan gugatan tidak dapat diterima, yang dikenal sebagai exceptio plurium litis consortium, para pihak yang diajukan sebagai Tergugat tidak lengkap, karena masih ada orang lain yang harus ikut dijadikan sebagi para pihak dalam perkara tersebut yang harus dimasukkan, sehingga persoalan dapat diselesaikan secara tuntas. Dalam hukum acara perdata tidak dikenal istilah turut penggugat, melainkan turut tergugat. Disebutkan sebagai turut tergugat dimaksudkan agar orang-orang, bukan para pihak yang bersengketa (penggugat dan tergugat) demi lengkapnya pihak-pihak, maka orang-orang bukan pihak yang bersengketa tersebut harus diikutsertakan dalam gugatan penggugat sekedar untuk tunduk dan taat terhadap putusan hakim. Hal ini telah menjadi suatu yurisprudensi sebagaimana diputus dalam Putusan Mahkamah Agung tanggal 28 Januari 1976 No. $201 \mathrm{~K} / \mathrm{Sip} / 1974 .{ }^{5}$ Suatu gugatan yang tidak lengkap para pihaknya, dengan pengertian masih terdapat orang-orang/badan hukum lain yang harus ikut digugat, tetapi tidak diikutkan, maka gugatan demikian dinyatakan tidak dapat diterima. Putusan tidak dapat diterimanya gugatan (niet onvankelijk verklaart) dijatuhkan dengan alasan-alasan:

a. gugatan tidak berdasarkan hukum;

b. gugatan tidak patut;

c. gugatan bertentangan dengan kesusilaan/ ketertiban umum; d. gugatan salah;

e. gugatan tidak memenuhi persyaratan;

f. obyek gugatan tidak jelas;

g. subyek gugatan tidak lengkap.

Terhadap putusan gugatan tidak dapat diterima, menimbulkan suatu konsekuensi hukum bahwa terhadap gugatan tersebut dapat diajukan lagi oleh si penggugat. Dalam perkara ini tentunya penggugat dirugikan, karena perkara sudah diputus dan penggugat sebagai pihak yang kalah, oleh karenanya tidak dapat mengajukan gugatan baru lagi (nebis in idem).

Berdasarkan hal tersebut, hakim dalam perkara ini seharusnya mempertimbangkan eksepsi para Tergugat terkait kedudukan yang dimiliki oleh pihak, karena pihak yang dapat berperkara di pengadilan adalah pihak yang mempunyai kepentingan, yaitu pihak yang mempunyai dasar hukum dan hubungan hukum yang cukup. Demi tuntasnya proses pemeriksaan, kesuluruhan pihak abik penggugat, tergugat, maupun turut tergugat kesemuaannya harus dilibatkan. Tidak lengkapnya pihak-pihak yang dilibatkan dalam surat gugatan, mengakibatkan gugatan cacat secara formil dan menimbulkan konsekuensi gugatan tidak dapat diterima.

Tidak cermatnya hakim dalam menjatuhkan putusan aquo, menimbulkan suatu ketidakpastian hukum, karena selain bertentangan dengan yurisprudensi juga bertentangan dengan Putusan Pengadilan Tinggi Semarang sebelumnya, yaitu Putusan No. 591/Pdt /2001/PT. Smg yang pada intinya merupakan perkara yang sejenis dengan putusan Pengadilan Tinggi No. 401/Pdt/2002/ PT. Smg ini, yang menekankan bahwa dengan tidak semua pihak yang menguasai atau terlibat dalam obyek sengketa ikut digugat oleh penggugat mengakibatkan gugatan tidak dapat diterima.

2. Dalam Pokok Perkara

Dalam gugatannya Penggugat mendalilkan bahwa Penggugatlah yang berhak atas obyek sengketa berupa sebidang tanah yang terletak di Desa Tambaksogra Kecamatan 
Sumbang Kabupaten Banyumas dengan batas-batas:

Sebelah Utara : Madisuwito/ saluran air

Sebelah Selatan : jalan raya

Sebelah Barat : tanah desa

Sebelah Timur : saluran air

Bukti yang diajukan oleh Penggugat tidak dapat mengukuhkan bahwa yang berhak atas obyek sengketa adalah pihak Penggugat, karena Penggugat tidak dapat mengajukan bukti bahwa perjanjian jual beli antara Peng-gugat dan Tergugat I adalah tidak sah. Dalam perkara ini, penggugat tidak dapat membantah adanya tanda tangan Penggugat dalam akte jual beli. Selain itu, Tergugat I, Tergugat II dan Tergugat III dapat mengajukan bukti lawan yang lebih kuat daripada Penggugat.

Berkaitan dengan peralihan hak atas tanah Pasal 37 ayat (1) Peraturan Pemerintah No. 24 tahun 1997 tentang Pendaftaran Tanah, merumuskan bahwa:

"Peralihan hak atas tanah dan hak milik atas satuan rumah susun melalui jual beli, tukar menukar, hibah, pemasukkan dalam perusahaan dan perbuatan hukum pemindahan hak lainnya, kecuali pemin-dahan hak melalui lelang, hanya dapat didaftarkan jika dibuktikan dengan akta yang dibuat oleh PPAT yang berwenang menurut ketentuan peraturan perundang-undangan yang berlaku."

Dalam perkara ini Tergugat dapat membuktikan bahwa peralihan hak telah sesuai dengan apa yang dikehendaki dalam peraturan pemerintah tersebut. Hal ini dibuktian dengan adanya akta jual beli No. 574.SGH/XII/1994 yang dilakukan di hadapan pejabat yang ber-wenang (dalam hal ini Notaris/PPAT Muhammad Turman, S.H.) dengan kata lain, peralihan hak atas tanah dari Penggugat ke Tergugat I melalui perjanjian jual beli yang dituangkan dalan Akta Jual Beli No. 574.SGH/XII/1994 adalah sah me-nurut hukum, karena telah dilakukan di hadap-an pejabat yang berwenang dan tentu saja sudah ditanda tangani oleh para pihak.
Untuk yang terakhir ini ada suatu adagium, bahwa pembubuhan tanda tangan adalah wujud dari suatu kesepakatan. Telah menjadi suatu yurisprudensi bahwa seeorang tidak dapat menyatakan secara sah, bahwa yang bersangkutan tertipu oleh pihak lain, apabila telah membubuhkan tanda tangan dalam suatu surat perjanjian tanpa membaca surat perjanjian itu terlebih dahulu (Putusan Pengadilan Tinggi Bandung, Yurisprudensi jawa Barat 1969-1972). ${ }^{6}$

Para pihak dalam proses pembuktian mengajukan alat bukti surat. Alat bukti surat menurut doktrin dapat dibedakan menjadi akta dan bukan akta. Akta sendiri dapat dibedakan menjadi:

a. Akta otentik, yaitu akta yang dibuat oleh atau di hadapan pejabat yang diberi wewenang untuk itu dan dalam bentuk menurut ketentuan yang ditetapkan untuk itu, baik dengan maupun tanpa bantuan dari yang berkepentingan, di tempat di mana pejabat berwenang menjalankan tugasnya (Pasal 1868 BW). Akta otentik dibedakan menjadi 2 (dua) macam, yaitu Akta yang dibuat oleh pejabat (acta ambtelijk, proces verbaal acte), yaitu akta yang dibuat oleh pejabat yang berwenang untuk itu karena jabatannya tanpa campur tangan pihak lain, dengan mana pejabat tersebut menerangkan apa yang dilihat, didengar serta apa yang dilakukannya dan akta yang dibuat di hadapan pejabat (partij acte), yaitu akta yang dibuat oleh para pihak di hadapan pejabat yang berwenang untuk itu atas kehendak para pihak, dengan mana pejabat tersebut menerangkan juga apa yang dilihat, didengar dan dilakukannya.

b. Akta Di Bawah Tangan ialah akta yang dibuat oleh para pihak dengan sengaja untuk pembuktian, tatapi tanpa bantuan dari seseorang. Hal ini diatur dalam Stbl 1867 No. 29 untuk Jawa dan Madura, sedang untuk luar Jawa dan Madura

I Rubini dan Chidir Ali, 1981, Yurisprudensi tentang Hukum Acara Pembuktian, Jilid II, Bandung: Bina Cipta, hlm. 121 
diatur dalam Pasal 286 sampai dengan 305 Rbg Pasal 1874 - 1180 BW.

Berdasarkan pembedaan tersebut, maka Akta Jual Beli No. 574.SGH/XII/1994 dapat dikualifikasikan sebagai partij acte yang merupakan akta otentik. Akta otentik sendiri mempunyai kekuatan pembuktian yang sempurna dan mengikat. Terhadap alat bukti ini dapat dilumpuhkan dengan bukti lawan dengan kekuatan pembuktian yang menentukan. Dalam perkara ini, nyata bahwa dari bukti-bukti yang diajukan oleh Penggugat tidak dapat mengukuhkan dalilnya, bahwa Penggugatlah yang berhak atas tanah tersebut atau dengan pengertian lain Penggugat tidak dapat membuktikan, bahwa akta jual beli tersebut adalah tidak sah dan karenanya batal demi hukum.

Kepastian hukum sebagaimana keadilan dan kemanfaatan hukum adalah sesungguhnya sebuah doktrin. Doktrin kepastian hukum mengajarkan kepada setiap pelaksana dan penegak hukum untuk (demi terkendalikannya kepatuhan warga agar ikut menjaga ketertiban dalam setiap aspek kehidupan) mendayagunakan hukum yang sama untuk kasus yang sama. Inilah doktrin kaum positivis, yang dikenali pula sebagai doktrin the supreme state of (national) law yang mengajarkan dan meyakini adanya status hukum yang mengatasi kekuasaan dan otoritas lain. Inilah doktrin yang berkonsekuensi pada ajaran lebih lanjut agar setiap ahli hukum, khususnya yang tengah bertugas sebagai hakim, tidak menggunakan rujukanrujukan normatif lain selain yang terbilang norma hukum guna menghukumi suatu perkara. ${ }^{7}$

Untuk menggambarkan hakim yang progresif, tidak lepas dari deskripsi standar tinggi tentang kompetensi keilmuan, kecakapan profesional, dan kualitas kepribadian yang dilekatkan pada hakim sebagai subjek penegak hukum. Dari putusan hakim yang tersebut dituntut konsekuensi etis munculnya kecerdasan moral, intelektual, dan emosional. Putusan berkualitas yang dihasilkannya dapat memberi-

Soetandyo Wignjosoebroto, 2006, Menggagas Terwujud nya Peradilan Yang Independen Dengan Hakim Profesional Yang Tidak Memihak. Buletin Komisi Yudisial. kan pencerahan rokhani bagi pihak yang berperkara, dan mempererat kohesi sosial dalam tata pergaulan masyarakat. Dalam upaya membangun penegakan hukum yang akuntabel, dituntut adanya kualitas pertanggungjawaban moral dan yuridis dari hakim. Proses penegakan hukum yang akuntabel harus selalu dapat dipertanggungjawabkan kepada publik, kebenaran ilmiah dan hati nurani. Lebih dari itu, yang terpenting ada pertanggungjawaban kepada Allah Yang Maha Mengetahui dan Maha Adil. Hukum yang baik seharusnya memberikan sesuatu yang lebih daripada sekedar prosedur hukum. Hukum tersebut harus berkompeten dan juga adil. Hukum seharusnya mengenai keinginan dan punya komitmen terhadap tercapainya keadilan substantif. ${ }^{8}$

Dalam hal ini, hakim harus melihat secara komprehensif mengenai kasus tersebut, untuk mencari keadilan bagi para pihak yang bersengketa. Mengenai hubungan keadilan dengan putusan hakim, maka terdapat norma yang termaktub dalam UU No.4 Tahun 2004 tentang Kekuasaan Kehakiman.

Pasal 4 ayat (1)

\section{"Peradilan dilakukan "Demi Keadilan Berdasarkan Ketuhanan YME”}

Pasal 26

“Hakim wajib menggali, mengikuti dan memahami nilai-nilai hukum dan rasa keadilan yang hidup dalam masyarakat."

Apabila putusan tersebut secara an sich hanya memeriksa pokok perkaranya, memang apa yang dijatuhkan oleh hakim dalam amarnya adalah sudah tepat. Hal ini disebabkan, proses peralihan hak sudah sesuai dengan prosedur hukum yang berlaku terkait dengan peralihan hak atas tanah.

Namun demikian, pemeriksaan suatu perkara harus dilakukan secara komprehensif, mulai dari hal-hal diluar pokok perkara sampai dengan pokok perkaranya sendiri. Hal-hal diluar pokok perkara biasanya diajukan oleh pihak

8 Philipe Nonet dan Philip Seiznick. 2003. Hukum Responsif: Pilihan di Masa Transisi. Jakarta: HuMa. 
tergugat, dalam hal ini dikenal dengan istilah eksepsi. Pada dasarnya eksepsi dapat dibedakan menjadi eksepsi kompetensi dan eksepsi diluar kompetensi. Eksepsi kompetensi sendiri dibedakan menjadi eksepsi kompetensi absolut dan eksepsi kompetensi relatif. Eksepsi kompetensi absolut harus diputuskan terlebih dahulu, sedangkan eksepsi kompetensi relatif dan eksepsi diluar kompetesi diputuskan oleh hakim bersamaan dengan pokok perkara. Kalimat "diputuskan oleh hakim bersamaan dengan pokok perkara" mengandung maksud, bahwa pemeriksaan antara eksepsi dan pokok perkara dilakukan secara bersamaan, akan tetapi dalam pertimbangan hukumnya hakim harus mempertimbangkan terlebih dahulu eksepsi yang diajukan pihak tergugat sebelum sampai pada pertimbangan pokok perkara. Apabila dalam pertimbangan hukum terkait dengan eksepsi terbukti bahwa pengadilan tidak berwenang atau terdapat cacat formil dalam surat gugatan, maka pemeriksaan terhadap pokok perkara tidaklah perlu dilanjutkan. Dalam praktik, hakim cenderung menggunakan kalimat "bahwa pertimbangan hukum terkait eksepsi secara mutatis mutandis diambil untuk mempertimbangkan pokok perkaranya", sehingga gugatan penggugat terkait dengan pokok perkara tidak dipertimbangkan lebih lanjut. Terhadap eksepsi dan pokok perkara, amarnya dijatuhkan sekaligus dalam suatu putusan. Hal ini berbeda dengan, eksepsi kompetensi absolut, dimana eksepsi ini dipertimbangkan dan diputuskan terlebih dahulu sebelum memeriksa, mempertimbangkan dan menjatuhkan putusan terkait pokok perkaranya.

Dalam perkara Putusan Pengadilan Tinggi Semarang No. 401/Pdt/2002/Smg jo Putusan Pengadilan Negeri Purwokerto tanggal 17 April 2001 No. 41/Pdt.G/2000/PN Pwt., pihak tergugat mengajukan eksepsi diluar kompetensi yang pada dasarnya mendalilkan bahwa masih ada pihak lain yang harus dimasukkan dalam surat gugatan. Eksespsi tersebut dapat dikualifikasikan sebagai eksepsi plurium litis consortium, yang menekankan bahwa Pihakpihak yang terlibat dalam sengketa harus dimasukkan dalam surat gugatan. Tidak dimasukannya pihak-pihak tersebut mengakibatkan gugatan tidak dapat diterima. Namun kenyataannya, dalam Putusan Pengadilan Tinggi Semarang No. 401/Pdt/2002/Smg jo Putusan Pengadilan Negeri Purwokerto tanggal 17 April 2001 No. 41/Pdt.G/2000/PN Pwt., hakim menolak eksepsi para tergugat dan langsung memeriksa pokok perkaranya. Padahal apabila dianalisis hubungan hukum yang terjadi antara penggugat dan Tergugat I, maupun hubungn hukum antara Tergugat I dengan Tergugat III pastilah melibatkan pihak lain, dalam hal ini adalam PPAT (Pejabat Pembuat Akte Tanah) dan Kantor Pertanahan. Pihak-pihak tersebut harus turut digugat atau dimasukkan dalam surat gugatan oleh Penggugat. Dalam hukum acara perdata kedudukan mereka dikualifikasikan sebagai turut tergugat dan harus dimasukkan dalam surat gugatan. Disebutkan sebagai turut tergugat dimaksudkan agar orang-orang, bukan para pihak yang bersengketa (penggugat dan tergugat) demi lengkapnya pihak-pihak, maka orang-orang bukan pihak yang bersengketa tersebut harus diikutsertakan dalam gugatan penggugat sekedar untuk tunduk dan taat terhadap putusan hakim. Hal ini telah menjadi suatu yurisprudensi sebagaimana diputus dalam Putusan Mahkamah Agung tanggal 28 Januari 1976 No. 201 K/Sip/1974. ${ }^{9}$

Berdasarkan hal tersebut, dapat disimpulkan sementara bahwa perkara dalam putusan ini berawal dari hubungan hukum antara pihak Penggugat dengan Tergugat I, dimana pihak Penggugat membantah akte jual beli yang dilakukan antara Penggugat dan Tergugat I, karena pihak Penggugat menganggap bahwa Tergugat I meminjam sertifikat tanahnya untuk kemudian dapat meminjam uang di bank, sekalipun pada kenyataannya proses peralihan hak tersebut melalui prosedur hukum yang tepat sehingga memunculkan sertifikat atas nama Tergugat । yang kemudian dijadikan sebagai jaminan di bank (Tergugat III). Oleh karena itu, apabila yang digugat adalah hubungan hukum terkait jual beli tanah yang mengakibatkan lahirnya sertifikat tanah atas

Chidir Ali, op.cit., hlm. 218 
nama Tergugat I, maka dalam hal ini pihak yang digugat cukuplah Tergugat I saja dengan kedudukan sebagai tergugat, sedangkan pihakpihak lainnya harus tetap dimasukkan dalam surat gugatan dan berkedudukan sebagai Turut Tergugat, yang dalam perkara ini adalah pihak PPAT, Bank dan Kantor Pelayanan Pengurusan Piutang Negara.

Putusan Pengadilan Tinggi yang memutuskan untuk menguatkan apa yang diputus oleh Pengadilan Negeri Purwokerto adalah tidak tepat. Hakim seharusnya memeriksa terlebih dahulu, apakah gugatan telah memenuhi syarat formil atau belum. Suatu gugatan yang tidak memenui syarat formil, maka akan mengakibatkan gugatan menjadi tidak dapat diterima. Hal ini menimbulkan konsekuensi hukum yang berbeda atas upaya yang ditempuh apabila tidak puas dengan putusan hakim. Dalam putusan yang menyatakan, bahwa gugatan penggugat tidak dapat diterima, maka atas gugatannya tersebut dapat diajukan gugatan baru lagi. Sedangkan terhadap putusan yang menjatuhkan bahwa gugatan ditolak, maka upaya hukum yang tersedia adalah banding.

Diabaikannya sumber-sumber hukum acara perdata dalam berproses di pengadilan akan berdampak pada ketercapaian kepastian hukum, kemanfaatan dan keadilan yang diharapkan dari suatu putusan hakim. Putusan hakim (aquo) yang telah mengabaikan eksepsi dari para Tergugat, menunjukkan bahwa hakim tidak cermat dalam menilai suatu surat gugatan, khususnya berkaitan dengan kedudukan para pihak. Hal ini mengakibatkan putusan dijatuhkan dengan mengabaikan proses beracara sebagaimana diatur dalam peraturan perundang-undangan maupun yurisprudensi, sehingga terdapat ketidakpastian hukum.

Ketercapaian kemanfaatan dan keadilan dalam perkara perdata bersifat relatif, yaitu bermanfaat dan adil bagi para pihak yang sengketanya diputus oleh hakim. Dalam perkara aquo, apabila eksepsi para pihak diabaikan, memang terdapat suatu fakta bahwa Penggugat tidak dapat membuktikan dalil bahwa hubungan hukum antara Penggugat dan Tergugat I tidak sah, sehingga apabila mendasarkan pada ke- benaran formil yang ingin dicapai dalam proses pengadilan perdata, maka Putusan Hakim aquo sudah tepat.

Kepastian hukum, keadilan dan kemanfaatan memang sulit untuk dicapai sekaligus dalam suatu putusan hakim, kecenderungan salah satu akan dikorbankan. Namun demikian, apa yang dilakukan oleh hakim dalam Putusan aquo menurut penulis bukanlah suatu contoh mengenai hal tersebut, karena dalam hal ini hakim telah mengabaikan prosedur proses beracara di pengadilan perdata yang diatur dalam sumber-sumber hukum acara perdata. Ketidakcermatan hakim dalam memberikan pertimbangan hukum terkait eksepsi yang diajukan oleh para tergugat merupakan alasan untuk dapat mengajukan kasasi dan putusan tersebut harus dibatalkan.

Selain itu, dengan ketidakcermatan hakim dalam menilai kedudukan para pihak, maka terhadap hakim yang memeriksa, baik di tingkat pengadilan negeri maupun pengadilan tinggi dapat diajukan untuk diperiksa oleh Komisi Yudisial. Sebagaimana diketahui, lahirnya Undang-undang No. 22 Tahun 2004 telah membentuk suatu lembaga baru yaitu Komisi Yudisial yang mempuyai kewenangan antara lain yaitu menegakkan kehormatan dan keluhuran martabat serta menjaga perilaku hakim. Terhadap hakim-hakim yang diperiksa, Komisi Yudisial kemudian membuat laporan hasil pemeriksaan yang berupa rekomendasi yang dapat berupa teguran tertulis, pemberhentian sementara; atau pemberhentian yang disampaikan kepada Mahkamah Agung dan/atau Mahkamah Konstitusi, serta tindasannya disampaikan kepada Presiden dan DPR.

\section{Penutup}

\section{Simpulan}

Hakim dalam menjatuhkan Putusan No. 401/Pdt/2002/Smg, Mejelis Hakim Pengadilan Tinggi Semarang yang menguatkan Putusan Pengadilan Negeri Purwokerto tanggal 17 April 2001 No. 41/Pdt.G/2000/PN Pwt adalah tidak cermat, karena seharusnya hakim memeriksa terlebih dahulu, apakah gugatan telah memenuhi syarat formil atau belum, dengan 
memperhatikan kedudukan para pihak dalam berperkara, karena kedudukan para pihak ini menimbulkan suatu konsekuensi hukum yang berbeda. Ketidakcermatan hakim dalam menjatuhkan putusan mengakibatkan tidak terpenuhinya unsur kepastian hukum, karena bertentangan dengan sumber-sumber hukum acara perdata, sekalipun apabila eksepsi dalam perkara tersebut diabaikan, memang terdapat fakta bahwa Penggugat tidak dapat membuktikan dalil-dalilnya, sehingga kemanfaatan dan keadilan relatif tercapai.

\section{Rekomendasi}

Hakim dalam peradilan perdata tidak harus mengetahui hukum materiil perdata, karena hukum materiil perdata dapat ditanyakan nantinya dalam proses pembuktian kepada saksi ahli. Namun, hakim dalam peradilan perdata wajib memahami proses beracara sebagaimana digariskan dalam HIR, Rbg, Undang-undang No. 4 Tahun 2004 tentang Kekuasaan Kehakiman, maupun peraturan perundangan lainnya yang mengatur tentang proses beracara di lingkungan peradilan perdata. Oleh karena itu, perlu ditingkatkan pemahaman tentang proses beracara, khususnya berkaitan dengan kedudukan para pihak yang berperkara, karena hal ini mempunyai konsekuensi hukum yang berbeda atas putusan hakim yang dijatuhkan. Selain itu, hakim yang memeriksa perkara, baik ditingkat pengadilan negeri maupun pengadilan tinggi dapat diajukan ke Komisi Yudisial untuk dapat diperiksa lebih lanjut.

\section{Daftar Pustaka}

Ali, Chidir. 1985. Yurisprudensi Hukum Acara Perdata Indonesia. Yogyakarta: CV Nur Cahya;

Harahap, M. Yahya. 2004. Hukum Acara Perdata. Jakarta: Sinar Grafika;

-.-.-.. 2005. Hukum Acara Perdata Tentang Gugatan, Persidangan, Penyitaan, Pembuktian dan Putusan Pengadilan. Jakarta: Sinar Grafika;

Mertokusumo, Sudikno. 2002. Hukum Acara Perdata Indonesia. Yogyakarta: Liberty;
Nonet, Philipe dan Philip Seiznick. 2003. Hukum Responsif: Pilihan di Masa Transisi, Jakarta: HuMa;

Prodjodikoro, Wirjono. 1978. Hukum Acara Perdata di Indonesia, Bandung: Sumur Bandung;

Rubini, I dan Chidir Ali. 1981. Yurisprudensi tentang Hukum Acara Pembuktian. Jilid II. Bandung: Bina Cipta

Wignjosoebroto, Soetandyo. 2006. Menggagas Terwujudnya Peradilan Yang Independen Dengan Hakim Profesional Yang Tidak Memihak. Buletin Komisi Yudisial. 